\title{
ANALISIS YURIDIS TERHADAP PRODUK HUKUM KETETAPAN MPR SETELAH PERUBAHAN UUD 1945
}

\author{
Drs Munif Rochmawanto, SH,MH,MM
}

\begin{abstract}
Abstrak
Salah salah satu berkah reformasi adalah perubahan Undang Undang Dasar 1945 dimana salah satu perubahan yang mendasar adalah menyangkut kedudukan, fungsi, tugas, dan wewenang lembaga Negara salah satunya adalah Majelis Permusyawaratan Rakyat (MPR). MPR tidak lagi memegang kedaulatan tertinggi akan tetapi kedaulatan tersebut berada di tangan rakyat dan dilaksanakan menurul Undang-undang Dasar sebagaimana Pasal 1 ayat (2) amandemen UUD 1945. Begitu juga kedudukan MPR tidak lagi sebagai lembaga Tertinggi Negara sebagaimana diatur dalam UUD 1945 (sebelum amandemen), tetapi berkedudukan sebagai lembaga tinggi negara dengan kedudukan yang sejajar dengan lembaga-lembaga tinggi negara lainnya dan merupakan lembaga gabungan dari DPR dan DPD. Produk hukum yang dikeluarkan oleh MPR berupa ketetapan MPR dimana berdasarkan Undang Undang Nomor 12 Tahun 2011 Tap MPR kedudukanya dibawah UUD.
\end{abstract}

\section{Kata kunci : Tap MPR}

\section{A. Pendahuluan}

\section{a. Latar Belakang Masalah}

Berlangsungnya reformasi

kehidupan kenegaraan, yang ditandai pula dengan perubahan terhadap Undang-Undang Dasar 1945, telah mengakibatkan terjadinya perubahan struktur kelembagaan negara yang berlaku di Negara Republik Indonesia yang pula telah mengakibatkan terjadinya perubahan kedudukan, fungsi, tugas, dan wewenang lembaga Negara dan lembaga pemerintahan yang ada. Perubahan-perubahan tersebut mempengaruhi aturan-aturan yang berlaku menurut UndangUndang Dasar Negara Republik Indonesia Tahun 1945 dan mengakibatkan perlunya dilakukan peninjauan terhadap materi dari status hukum ketetapan Majelis Petmusyawaratan Rakyat Sementara (MPRS) dan Majelis Permusyawaratan Rakyat (MPR) Republik Indonesia.

\section{Perubahan UUD 1945 yang telah merubah secara mendasar pengaturan terhadap Majelis Permusyawaratan Rakyat menyangkut beberapa hal, sebagai berikut :}

1. MPR tidak lagi memegang kedaulatan tertinggi sebagaimana disebutkan dalam Pasal 2 ayat (1)
UUD 1945 sebelum amandemen UUD 1945, akan tetapi kedaulatan tersebut berada di tangan rakyat dan dilaksanakan menurul Undangundang Dasar Pasal 1 ayat (2) Perubahan Ketiga UUD 1945).

2. MPR tidak lagi berkedudukan sebagai lembaga Tertinggi Negara sebagaimana diatur dalam UUD 1945 (sebelum amandemen), tetapi berkedudukan sebagai lembaga tinggi negara dengan kedudukan yang sejajar dengan lembagalembaga tinggi negara lainnya.

3. MPR tidak lagi beranggotakan dan/atau terdiri dari utusan golongan dan utusan daerah serta DPR, akan tetapi terdiri dari Dewan Perwakilan Rakyat (DPR) dan Dewan Perwakilan Daerah (DPD).

4. Terjadi perubahan terhadap kewenangan yang dimiliki oleh MPR berdasarkan pasal 3 amandemen UUD 1945.

Berdasarkan pada amandemen UUD 1945, yang menimbulkan pemasalahan-permasalahan

menyangkut kedudukan produk hukum yang dihasilkan oleh MPR berupa Ketetapan MPR.

Ketetapan MPR No. III/MPR/2000 tentang Sumber Hukum dan Tata Urutan Peraturan Perundangundangan, menempatkan Ketatapan 
MPR sebagai sumber hukum dan tatanan hirarki peraturan perundangundangan di Negara Republik Indonesia. Munculnya Undang Undang Nomor 10 Tahun 2004 mengatur tata urutan peraturan perundang-undangan yang di dalamnya tidak menempatkan Ketetapan (TAP) MPR sebagai tata hirarki peraturan perundang-undangan yang berlaku di Indonesia. Kenyataan yuridis ini menimbulkan pertanyaan terhadap kedudukan Tap MPRS dan MPR yang telah ada sebelum berlakunya Undang Undang Nomor 10 Tahun 2004 tersebut. Hal ini memberikan arti bahwa Tap MPR tersebut tidak lagi dapat dijadikan sebagai dasar bagi peraturan perundang-undangan.

Kemudian dalam Pasal I

Aturan Tambahan UUD 1945 (amandemen) telah menginstruksikan kepada MPR untuk segera melakukan tinjauan terhadap keberadaan Ketatanan MPR pada Sidang Tahunan MPR tahun 2003. Kemudian MPR mengeluarkan Ketatapan MPR No. 1 /MPR/2003 tentang Peninjauan Terhadap Materi dan Status Hukum Ketetapan Majelis Permusyawaratan Rakyat Sementara dan Ketetapan Majelis Permusyawaratan Rakyat Republik Indonesia Tahun 1960 sampai dengan Tahun 2002. Dalam ketetapan MPR ini ada beberapa ketetapan yang dicabut keberadaannya dan ada pula yang masih tetap berlaku. Namun demikian hal ini masih tetap menjadi pertanyaan tentang kekuatan mengikat dari Tap MPR yang mana berdasarkan pada UU No. 10 Tahun 2004 tidak lagi menjadi sumber hukum dan tata hirarki peraturan perundang-undangan. Kemudian berdasarkan Undang Undang Nomor 12 Tahun 2011, ketetapan MPR kembali menjadi sumber hukum dan hirarkhi peraturan perundang undangan yang menempati posisi di bawah Undang Undang Dasar.

Dengan adanya perubahan tersebut, kedudukan lembaga-lembaga Negara yang ada tetap berlaku sebelum adanya perubahan yang tetap. Hal ini didasarkan pada Aturan Peralihan Pasal I UUD 1945 (Amandemen) yang berbunyi: "Segala peraturan perundang-undangan yang ada masih tetap berlaku selama belum diadakan yang baru menurut UndangUndang Dasar ini. Kemudian aturan peralihan Pasal II yang berbunyi: "Semua lembaga Negara yang ada masih tetap berfungsi sepanjang untuk melaksanakan ketentuan UndangUndang Dasar dan belum diadakan yang baru menurut Undang-Undang Dasar ini.

\section{B. Perumusan Masalah}

a. Bagaimana Kedudukan TAP MPR dalam tata urutan Peraturan Perundang-undangan?

b. Produk hukum apa yang dapat dikeluarkan MPR setelah Amandemen Undang Undang dasar 1945 ?

\section{Tujuan Penelitian}

1. Untuk mengetahui kedudukan TAP MPR dalam tata urutan Peraturan Perundang-undangan.

2. Untuk mengetahui produk hukum yang dapat dikeluarkan MPR setelah dilakukan Amandemen UUD 1945.

\section{B. Kajian Pustaka}

\section{Pengertian Negara Hukum}

Dalam kepustakaan Indonesia istilah negara hukum merupakan terjemahan langsung dari rechtsstaat. Demikian juga dikemukakan oleh Notohamidjojo: ${ }^{85}$

\footnotetext{
85 Azhary, Negara Hukum Indonesia, Analisa Yuridis Normatif tentang unsur-unsurnya, UI Press, Jakarta, 1995, hal 30.
} 
"Dengan timbulnya gagasan-gagasan pokok yang dirumuskan dalam konstitusi-konstitusi dari abad IX itu, maka timbul juga istilah negara hukum atau rechtsstaat."

Selain itu, Yamin juga berpendapat sama :

"Republik Indonesia ialah suatu negara hukum (rechsstaat, government of laws) tempat keadilan yang tertulis berlaku, bukanlah negara polisi atau negara militer, tempat polisi dan prajurit memegang pemerintah dan keadilan, bukanlah pula negara kekuasaan (machtstaat) tempat tenaga senjata dan kekuatan badan melakukan sewenangwenang." $" 86$

Bagaimana pengertian Negara Hukum di Indonesia? R. Djokosutono, mengatakan bahwa negara hukum menurut UUD 1945 adalah berdasarkan pada kedaulatan hukum. Hukumlah yang berdaulat. Negara adalah merupakan subyek hukum, dalam arti rechstaat (badan hukum publik). Karena negara itu dipandang sebagai subyek hukum, maka jika ia bersalah dapat dituntut di depan pengadilan karena perbuatan melanggar hukum. ${ }^{87}$

Dalam pasal 1 ayat 3 UUD 1945 dikatakan bahwa "Negara Indonesia adalah Negara hukum itu artinya bahwa Negara berdasarkan atas hukum (rechstaat) tidak berdasarkan atas kekuasaan belaka (machstaat). Oleh karena itu negara tidak boleh melaksanakan aktifitasnya atas dasar kekuasaan belaka, tetapi harus berdasarkan hukum. Selanjutnya penjelasan UUD 1945 itu menerangkan bahwa "Pemerintahan berdasar atas sistem konstitusional (hukum dasar) tidak bersifat absolutisme (kekuasaan yang terbatas), karena kekuasaan eksekutif dan administrasi, di Indonesia berada dalam satu tangan, yaitu ada pada presiden maka administrasi harus berdasar asas konstitusional tidak bersifat absolut. Artinya administrasi dalam menjalankan tugasnya dibatasi oleh peraturan perundangan.

Ismaii Suny, dalam brosur mekanisme beliau Demokrasi Pancasila mengatakan, bahwa negara hukum Indonesia memuat unsur-unsur, yaitu: (1) Menjunjung tinggi hukum; (2) Adanya pembagian kekuasaan; (3) Adanya perlindungan terhadap hak asasi manusia serta remedi-remedi prosudural untuk mempertahankannya; dan (4) Dimungkinkan adanya peradilan administrasi. ${ }^{88}$

\section{Unsur-unsur Negara Hukum}

Sebagai ciri pertama dari negara hukum adalah adanya pengakuan dan perlindungan atas hak-hak-asasi manusia. Tentang ciri ini bisa kita temui jaminannya di dalam Pembukaan dan Batang Tubuh Undang-Undang Dasar 1945, yaitu di dalam Pembukaan alinea I bahwa kemerdekaan ialah segala bangsa, kemudian di dalam alinea IV disebutkan pula salah satu dasar yaitu "kemanusiaan yang adil dan beradab", sedangkan di dalam Batang Tubuh Undang-Undang Dasar 1945 dapat kita temui beberapa pasal seperti Pasal 27 (persamaan kedudukan setiap warga negara di dalam hukum dan pemerintahan serta persamaan hak alas pekerjaan dan penghidupan yang layak), Pasal 28 (jaminan kemerdekaan untuk berserikat dan berkumpul serta mengeluarkan pikiran), Pasal 31 (jaminan hak untuk mendapatkan pengajaran). Jadi tentang ciri pertama ini sudah terpenuhi. ${ }^{89}$

Sebagai ciri kedua dari negara hukum adalah adnya peradilan yang bebas dari pengaruh sesuatu kekuasaan atau kekuatan lain dan tidak memihak.

\footnotetext{
${ }^{86}$ Ibid, hal 31

${ }^{87}$ Ibid, hal 90
} 
Untuk ciri kedua ini dapat dilihat Pasal 24 Undang-Undang Dasar 1945 yang menegaskan: "Kekuasaan kehakiman dilakukan oleh sebuah Mahkamah Agung dan lain-lain badan kehakiman menurut undang-undang." 90

Di dalam penjelasan terhadap Pasal 24 ini dijelaskan bahwa "kekuasaan kehakiman ialah kekuasaan yang merdeka artinya terlepas dari pengaruh kekuasaan pemerintah". Berhubung dengan itu harus diadakan jaminan di dalam undang-undang tentang kedudukan para hakim. Dengan begitu maka untuk ciri kedua negara hukum dapat dipenuhi oleh Undang-Undang Dasar 1945. ${ }^{91}$

Adapun ciri ketiga dari negara hukum adalah legalitas dalam arti hukum segala bentuknya. Ini dimaksudkan bahwa untuk segala tindakan seluruh warga negara, baik rakyat biasa maupun penguasa haruslah dibenarkan oleh hukum. Di Indonesia berbagai peraturan untuk segala tindakan sudah ada ketentuannya, sehingga untuk setiap tindakan itu harus sah menurut aturan hukum yang telah ada. Untuk mengamankan ketentuan tersebut maka di Indonesia telah dibentuk berbagai badan peradilan untuk memberi pemutusan (peradilan) terhadap hal-hal yang dianggap melakukan hal-hal yang tidak dibenarkan oleh hukum. ${ }^{92}$

Jadi semua landasan yang menjadi ciri dari negara hukum dapat ditemui di dalam Undang-Undang Dasar 1945 sehingga urttuk disebut negara hukum Undang-Undang Dasar 1945 cukup memberikan jaminan. Yang sering menjadi persoalan adalah pelaksanaannya di lapangan yang

\footnotetext{
${ }^{90}$ Ibid

${ }^{91}$ Ibid

92 Ibid, hal 87
}

kerapkali menimbulkan pertanyaan tentang relevansnya. ${ }^{93}$

Menurut John Locke kekuasaan negara itu terdiri atas : pertama, kekuasaan pembentuk undang-undang (legisiatif); kedua, kekuasaan pelaksanan undang-undang; dan ketiga; kekuasaan federatif. Dan John Locke adalah juga orang pertama yang mengemukakan pemikiran tentang pemisahan ketiga kekuasaan tadi. Buah pikirannya ini kemudian dipopulerkan oleh Montesquieu. ${ }^{94}$

Berdasarkan hal-hal yang dikemukakan John Locke itu, maka:

1. Negara bertujuan menjamin hak hak asasi warga negara.

2. Penyelenggaraan negara berdasar atas hukum.

3. Adanya pemisahan kekuasaan negara demi kepentingan hukum.

4. Supremasi dan kekuasaan peanbentuk undang-undang yang tergantung pada kepentingan rakyat.

Maka dapatlah dikatakan bahwa John Locke merupakan orang pertama yang meletakkan dasar pemikiran tentang unsur negara hukum.

\section{Metode Penelitian}

1. Tipe Penelitian

Tipe penelitian hukum yang dilakukan adalah yuridis normatif (hukum normatif) yaitu suatu prosedur penelitian ilmiah untuk menemukan kebenaran berdasarkan logika keilmuan hukum dari sisi normatifnya. $^{95}$

Oleh karena itu penelitian hukum ini difokuskan untuk mengkaji penelitian

\footnotetext{
${ }^{93}$ Ibid

94 Azhary, Op. Cit. hal 27

95 Johnny Ibrahim, Teori \& Metode

Penelitian Hukum Normatif, Banyumedia

Publishing, Malang 2006, h..57
} 
hukum tentang kaidah-kaidah atau norma-norma dalam hukum positif, yakni norma hukum yang terkait dengan produk hukum ketetapan Majelis Permusyawaratan Rakyat.

\section{Pendekatan Masalah}

Oleh karena tipe penelitian yang digunakan adalah tipe penelitian yuridis normatif, maka pendekatan yang digunakan adalah pendekatan perundang-undangan (statute approach) yaitu melakukan pengkajian peraturan perundangundangan yang berhubungan dengan pokok permasalahan. Selain itu juga digunakan pendekatan konsep (Conceptual approach) yaitu digunakan dalam rangka untuk melihat konsep konsep yang terkai dengan ketetapam Majelis Permusyawaratan Rakyat.

\section{Bahan Hukum}

Bahan hukum yang dipergunakan dalam penelitian ini adalah sebagai berikut :

1. Bahan hukum primer: bahan hukum primer merupakan bahan hukum yang bersifat autoritatif artinya mempunyai otoritas bahan hukum terdiri dari perundang-undangan, catatan resmi, atau risalah dalam pembuatan perundang-undangan dan putusan hakim. Adapun bahan hukum primer antara lain: Undang Undang Dasar 1945, Undang Undang Nomor 12 Tahun 2011, Undang Undang Nomor 17 Tahun 2014.

2. Bahan sekunder, yaitu bahan yang diperoleh dari buku teks, jurnal-jurnal, pendapat para sarjana dan kasus-kasus hukum. ${ }^{96}$

\section{Prosedur Pengumpulan Bahan- bahan}

96 Peter Mahmud Marzuki. Penelitian Hukum. Universitas Air Langga. Surabaya. h. 15.
Baik bahan primer maupun bahan sekunder dikumpulkan berdasar-kan topik permasalahan yang telah dirumuskan dan diklasifikasi menurut sumber dan hirarkinya untuk dikaji secara komprehensif.

\section{Pengolahan dan Analisis Bahan Hukum}

Adapun bahan yang diperoleh dalam penelitian studi kepustakaan, aturan perundangundangan, yang penulis uraikan dan dihubungkan sedemikian rupa, sehingga disajikan dalam penulisan yang lebih sistematis guna menjawab perumusan masalah yang dirumuskan. Cara pengolahan data dilakukan secara deduktif yakni menarik kesimpulan dari suatu permasalahan yang bersifat umum terhadap permasalahan kongkrit yang dihadapi.

\section{Pembahasan}

\section{Kedudukan MPR Pasca} Amandemen UUD 1945.

Salah satu perubahan mendasar dalam UUD 1945 adalah perubahan dalam Bab I tentang Bentuk dan Kedaulatan, khususnya Pasal 1 Ayat (2). Perubahan dalam Pasal 1 Ayat (2) telah mengubah struktur kekuasaan negara sebagai implementasi dari prinsip kedaulatan rakyat. Perubahan tersebut membawa konsekuensi perubahan struktur kelembagaan negara dan wewenang lembagalembaga negara. Pasal 1 Ayat (2) sebelum perubahan menyatakan "Kedaulatan adalah di tangan rakyat, dan dilakukan sepenuhnya oleh Majelis Permusyawaratan Rakyat." Ketentuan tersebut pasca amandemen berubah menjadi "Kedaulatan berada di tangan rakyat dan dilaksanakan menurut Undang-Undang Dasar". Perubahan tersebut setidaknya membawa lima konsekuensi dasar. Pertama, penegasan bahwa prinsip demokrasi yang merupakan wujud 
kedaulatan rakyat dalam pelaksanaannya harus mengikuti prinsip negara hukum yang berpuncak pada supremasi konstitusi. Kedua, Majelis Permusyawaratan Rakyat (MPR) tidak lagi memegang kekuasaan sebagai pelaksana sepenuhnya kedaulatan rakyat, sehingga dengan sendirinya tidak lagi menjadi lembaga tertinggi negara. Ketiga, kedaulatan rakyat dilaksanakan oleh organ-organ konstitusi sesuai dengan yang ditentukan oleh UUD, sehingga organorgan itu tidak dapat lagi dibedakan secara hierarkis (setidaknya dapat dikatakan sederajat), tetapi dibedakan menurut fungsi dan wewenang yang diberikan oleh UUD 1945. Keempat, terjadi perubahan wewenang yang dimiliki oleh lembaga negara, khususnya MPR. Kelima, terjadi perubahan hubungan antara lembaga negara yang lebih mencerminkan prinsip saling mengawasi dan mengimbangi. Sebelum Perubahan UUD 1945, MPR adalah pelaksana sepenuhnya kedaulatan rakyat sehingga lembaga-lembaga negara lain memperoleh mandat dari MPR. Untuk menjalankan kekuasaan tersebut, UUD 1945 sebelum perubahan memberikan wewenang kepada MPR untuk menetapkan UUD dan garis-garis besar dari pada haluan negara (Pasal 3 sebelum Perubahan). Untuk menjalankan wewenang tersebut produk hukum yang dihasilkan oleh MPR adalah UUD dan Ketetapan MPR. Lembaga-lembaga tinggi negara menjalankan mandat untuk melaksanakan ketetapan MPR dan mempertanggungjawabkan kepada MPR. Adanya perubahan implementasi prinsip kedaulatan rakyat dalam UUD 1945 mengakibatkan perubahan kedudukan dan wewenang MPR. Sejak semua lembaga negara mendapatkan kekuasaan dari UUD 1945, maka MPR tidak lagi memiliki wewenang membentuk Ketetapan MPR. MPR lebih berfungsi sebagai lembaga konstituante (berwenang mengubah dan menetapkan UUD) dan berfungsi "semacam" joint session dari dua lembaga parlemen, yaitu DPR dan DPD. Oleh karena itu Ketentuan Pasal 3 UUD 1945 berubah menjadi "Majelis Permusyawaratan Rakyat berwenang mengubah dan menetapkan Undang-Undang Dasar". Perubahan tersebut di atas telah ditindaklanjuti oleh MPR sendiri melalui Ketetapan MPR Nomor I/MPR/2003 tentang Peninjauan Terhadap Materi dan Status Hukum Ketetapan Majelis Permusyawaratan Rakyat Sementara dan Ketetapan Majelis Permusyawaratan Rakyat Republik Indonesia Tahun 1960 Sampai Dengan Tahun 2002. Konsideran menimbang huruf $\mathrm{b}$ dan huruf $\mathrm{c}$ Ketetapan MPR Nomor I/MPR/2003 menunjukkan bahwa ketetapan ini lahir karena perubahan struktur kelembagaan negara dan perubahan kedudukan, fungsi, tugas, dan lembaga negara. Tap MPR Nomor I/MPR/2003 menentukan 6 kategori status hukum Tap MPRS/MPR yang sudah ada, yaitu:

1) Tap MPR yang dicabut dan dinyatakan tidak berlaku;

2) Tap MPR yang dinyatakan tetap berlaku;

3) Tap MPR yang berlaku sampai dengan terbentuknya pemerintahan hasil Pemilu 2004;

4) Tap MPR yang tetap berlaku sampai dengan terbentuknya UU yang mengatur substansi yang sama;

5) Tap MPR tentang Tata Tertib MPR RI yang masih berlaku sampaiditetapkannya Peraturan Tata tertib MPR yang baru; dan

6) Tap MPR yang tidak perlu dilakukan tindakan hukum lebih lanjut karena bersifat einmalig. Berdasarkan kategori di atas, walaupun MPR tidak lagi berwenang 
membentuk Ketetapan namun masih terdapat kategori Tap MPR yang masih tetap berlaku dan tidak dapat dicabut atau diganti dengan undangundang, serta kategori Tap MPR yang dapat masih berlaku sepanjang belum diatur dalam UU. KetetapanKetetapan MPR yang masih tetap berlaku dan tidak dapat dicabut atau diganti dengan undang-undang adalah:

1) Tap MPRS Nomor XXV/MPRS/1966 tentang

Pembubaran Partai Komunis Indonesia, Pernyataan Sebagai Organisasi Terlarang di Seluruh Wilayah Negara Republik Indonesia bagi Partai Komunis Indonesia dan Larangan Setiap Kegiatan untuk Menyebarkan atau Mengembangkan Faharn atau Ajaran Komunis/MarxismeLeninisme; dan

2) Tap MPR Nomor XVI/MPR/1998 tentang Politik Ekonomi dalam Rangka Demokrasi Ekonomi; Sesungguhnya dalam Pasal 2 Tap MPR Nomor I/MPR/2003 terdapat satu ketetapan lain yang dinyatakan masih berlaku, yaitu Ketetapan Majelis Permusyawararan Rakyat Republik Indonesia Nomor V/MPR/1999 tentang Penentuan Pendapat di Timor Timur. Namun disebutkan bahwa Tap itu masih tetap berlaku sarnpai dengan terlaksananya ketentuan dalam Pasal 5 dan Pasal 6 Ketetapan Majelis Permusyawaratan Rakyat Republik Indonesia Nomor V/MPR/1999. Dengan telah selesainya pemisahan TimorTimur berdasarkan hasil jajak pendapat dan telah menjadi negara sendiri yang diakui Indonesia maka Ketetapan itu sudah selesai dilaksanakan.

Sedangkan Tap MPR yang dapat masih berlaku sepanjang belum diatur dalam UU, meliputi:
1) Tap MPRS Nomor XXIX/MPRS/1966 tentang

Pengangkatan Pahlawan Ampera;

2) Tap MPR Nomor $X I / M P R / 1998$ tentang Penyelenggara Negara yang Bersih dan Bebas Korupsi Kolusi, dan Nepotisme.

3) Tap Nomor XV/MPR/1998 tentang Penyelenggaraan Otonomi Daerah;

Pengaturan Pembagian, dan Pemanfaatan Sumber Daya Nasional yang Berkeadilan; serta Perimbangan Keuangan Pusat dan Daerah dalam Kerangka Negara Kesatuan Republik Indonesia.

4) Tap MPR Nomor III/MPR/2000 tentang Sumber Hukum dan Tata Urutan Peraturan Perundangundangan.

5) Tap MPR Nomor V/MPR/2000 tentang Pemantapan Persatuan dan Kesatuan Nasional.

6) Tap MPR Nomor VI/MPRI2000 tentang Pemisahan Tentara Nasional Indonesia dan Kepolisian Negara Republik Indonesia.

7) Tap MPR Nomor VII/MPR/2000 tentang Peran Tentara Nasional Indonesia dan Peran Kepolisian Negara Republik Indonesia.

8) Tap MPR Nomor VI/MPR/200I tentang Etika Kehidupan Berbangsa.

9) Tap MPR Nomor VII/MPR/2001 tentang Visi Indonesia Masa Depan.

10) Tap MPR Nomor VIII/MPR/200I tentang Rekomendasi Arah Kebijakan Pemberantasan Pencegahan Korupsi, Kolusi, dan Nepotisme.

11) Tap MPR Nomor IX/MPR/2001 tentang Pembaruan Agraria dan Pengelolaan Sumber Daya Alam.

Saat ini telah terdapat beberapa Undang-Undang yang mengatur substansi Tap di atas sehingga berdasarkan Pasal 4 Tap MPR Nomor I/MPR/2003 Tap terkait sudah tidak berlaku, walaupun dalam UU itu tidak mecabut Tap MPR terkait. Misalnya Ketetapan MPR Nomor III/MPR/2000 
tentang Sumber Hukum dan Tata Urutan Peraturan PerundangUndangan, substansinya telah diatur dalam UU Nomor 10 Tahun 2004 yang kemudian diganti dengan UU Nomor 12 Tahun 2011.

\section{Kedudukan Tap MPR dalam peraturan perundang-undangan} Sebelum dikeluarkannya Undang Undang Nomor 12 Tahun 2011, jenis dan hierarki peraturan perundang-undangan diatur dalam Tap MPRS Nomor XX/MPRS/1966, Tap MPR Nomor III/MPR/2000, kemudian diganti dengan UU Nomor 10 Tahun 2004 tentang Pembentukan Peraturan Perundang-Undangan, kemudian Undang Undang tersebut telah dicabut dengan dikeluarkannya Undang Undang Nomor 12 tahun 2011. Di dalam Pasal 7 ayat (1) UU Nomor 10 Tahun 2004 disebutkan jenis dan hierarki peraturan perundangundangan di mana di dalamnya tidak termasuk Ketetapan MPR. Pertanyaan hukum yang muncul adalah apakah dengan demikian dalam sistem peraturan perundang-undangan berdasarkan UU tersebut tidak lagi dikenal produk hukum Ketetapan MPR dan dengan sendirinya Ketetapan MPR tidak lagi memiliki kekuatan hukum mengikat? Untuk menjawab pertanyaan tersebut tentu tidak hanya melihat pada ketentuan Pasal 7 UU Nomor 10 Tahun 2004, tetapi juga melihat pada ketentuan yang terdapat dalam UUD 1945, terutama ketentuan peralihan. Pasal I Aturan Peralihan UUD 1945 menyatakan "Segala peraturan perundang-undangan yang ada masih tetap berlaku selama belum diadakan yang baru menurut UndangUndang Dasar ini". Ketentuan ini menjadi dasar hukum bahwa semua peraturan perundang-undangan, bukan hanya ketetapan MPR, bahkan peraturan yang dibuat pada masa kolonial, masih memiliki kekuatan hukum sepanjang belum diadakan yang baru. Selanjutnya, ketentuan Pasal I Aturan Tambahan UUD 1945 menyatakan "Majelis Permusyawaratan Rakyat ditugasi untuk melakukan peninjauan terhadap materi dan status hukum Ketetapan Majelis Permusyawaratan Rakyat Sementara dan Ketetapan Majelis Permusyawaratan Rakyat untuk diambil putusan pada Sidang Majelis Permusyawaratan Rakyat tahun 2003". Ketentuan ini merupakan dasar hukum lahirnya Tap MPR Nomor I/MPR/2003. Dengan demikian, walaupun di dalam jenis dan hierarki tidak lagi menyebutkan Ketetapan MPR sebagai jenis peraturan perundang-undangan, namun Ketetapan MPR masih tetap sah berlaku sebagai produk hukum nasional. Dasar hukumnya adalah ketetapan MPR Nomor I/MPR/2003. Dapat dipermasalahkan apa dasar hukum Tap MPR Nomor I/MPR/2003 padahal dalam UUD 1945 MPR sudah tidak memiliki wewenang membentuk Ketetapan MPR lagi? Dasar hukumnya adalah Pasal I Aturan Peralihan dan Pasal I Aturan Tambahan UUD 1945. Perubahan UUD 1945 memang tidak lagi memberikan wewenang kepada MPR untuk membentuk produk hukum ketetapan MPR, namun sama sekali tidak menyatakan bahwa Ketetapan MPR yang sudah ada tidak lagi memiliki kekuatan hukum. Selain justifikasi normative itu, keberlakuan suatu produk hukum yang tidak lagi dapat dibentuk juga ada dalam praktik, misalnya produk hukum Ordonansi yang dibentuk pada masa pemerintahan Hindia Belanda dan produk hukum Penetapan Presiden dan Undang-Undang Darurat yang banyak dibentuk pada masa Orde Lama. Semua ketentuan itu masih berlaku dan memperoleh legitimasi terutama dari ketentuan peralihan di dalam UUD. 
Undang Undang Nomor 12 Tahun 2011 dibentuk menggantikan UU Nomor 10 Tahun 2004. Salah satu perubahan substansi adalah Penambahan Ketetapan MPR sebagai salah satu jenis peraturan perundangundangan dan hierarkinya diletakkan di atas UU di bawah UUD 1945. Penjelasan Pasal 7 ayat (1) huruf b UU Nomor 12 Tahun 2011 menyatakan bahwa yang dimaksud dengan Ketetapan MPR adalah Ketetapan MPRS dan Ketetapan MPR sebagaimana dimaksud dalam Pasal 2 dan Pasal 4 Ketetapan MPR Nomor I/MPR/2003. Dengan demikian tidak semua ketetapan MPR yang pernah ada lalu menjadi berlaku berdasarkan UU ini, tetapi sebatas pada ketetapan MPR yang masih berlaku berdasarkan Pasal 2 dan Pasal 4 Ketetapan MPR Nomor I/MPR/2003 sebagaimana telah diuraikan sebelumnya.

Telah diuraikan bahwa walaupun di dalam UU Nomor 10 Tahun 2004 Ketetapan MPR tidak masuk dalam jenis dan hierarki peraturan perundangundangan, namun tetap memiliki kekuatan hukum mengikat berdasarkan Tap MPR Nomor I/MPR/2003 yang diakui berdasarkan Aturan Peralihan dan Aturan Tambahan UUD 1945. Oleh karena itu, masuknya Ketetapan MPR dalam jenis dan hierarki peraturan perundang-undangan menurut UU Nomor 12 Tahun 2011 hanya merupakan penegasan semata. Tidak ada konsekuensi hukum yang lebih kuat lagi. Sebaliknya, masuknya Ketetapan MPR dalam jenis dan hierarki peraturan perundangundangan justru melahirkan persoalan hukum baru, yaitu pertentangan antara Ketentuan Pasal 4 Ketetapan MPR Nomor I/MPR/2003 dengan Pasal 7 ayat (1) UU Nomor 12 Tahun 2011. Ketentuan Pasal 4 Tap MPR Nomor I/MPR/2003 menyatakan bahwa beberapa Ketetapan MPR masih tetap berlaku sampai dengan terbentuknya UU. Di sisi lain, Pasal 7 ayat (1) UU Nomor 12 Tahun 2011 menempatkan Ketetapan MPR di atas UU yang dari sisi hirarki hukum mengandung konsekuensi bahwa produk hukum UU tidak boleh bertentangan dengan Ketetapan MPR, konsekuensinya produk hukum UU tidak dapat menyatakan ketentuan yang lebih tinggi tidak berlaku. Ketentuan ini tentu bertentangan dengan Pasal 4 Tap MPR Nomor I/MPR/2003 yang menyatakan bahwa terdapat ketetapan MPR yang akan menjadi tidak berlaku jika sudah diatur dalam UU. Namun jika menggunakan logika UU Nomor 12 Tahun 2011 yang menempatkan Ketetapan MPR di atas UU, maka yang harus digunakan adalah ketentuan Pasal 4 Tap MPR Nomor I/MPR/2003 dimana substansinya justru menegasikan Pasal 7 UU Nomor 12 Tahun 2011 itu sendiri. Pertentangan ini juga membawa konsekuensi kepada persoalan kemungkinan pengujian Ketetapan MPR. Masuknya Ketetapan MPR sebagai jenis produk hukum dibawah UUD 1945 menimbulkan pertanyaan bagaimana jika terdapat ketentuan dalam Ketetapan MPR yang dinilai bertentangan dengan UUD 1945, padahal MPR sudah tidak lagi memiliki wewenang untuk membentuk Tap MPR yang mencabut atau mengubahnya. MK tentu diragukan kewenangannya untuk menguji Ketetapan MPR karena Ketetapan MPR bukan Undang-Undang dan kedudukannya berada di atas UU. Pertanyaan ini sesungguhnya juga muncul pada saat Ketetapan MPR tidak masuk dalam hierarki peraturan perundang-undangan. Namun pertanyaan itu dapat dijawab dengan merujuk kepada Ketetapan MPR Nomor I/MPR/2003. MK memiliki wewenang menguji Tap MPR, khusus untuk Ketetapan MPR yang disebut di dalam Pasal 4 Tap MPR Nomor 
I/MPR/2003, karena ketentuan pasal itu telah menyamakan kedudukan Ketetapan MPR terkait dengan UU. Sedangkan terhadap Ketetapan MPR yang ditentukan dalam Pasal 2 Tap MPR Nomor I/MPR/2003, MK tidak memiliki wewenang menguji karena ketentuan Pasal 2 itu sendiri tidak memungkinkan adanya perubahan atau pencabutan dengan UU. Ketetapanketetapan MPR dalam Pasal 2 Tap MPR Nomor I/MPR/2003 dapat diposisikan sebagai bagian dari konstitusi secara luas.

Sebelum adanya perubahan UUD 1945, bentuk-bentuk putusan MPR terdiri dari ketetapan dan keputusan. Ketetapan MPR adalah putusan majelis yang mempunyai kekuatan hukum mengikat ke luar dan ke dalam majelis. Keputusan MPR yang mempunyai kekuatan hukum mengikat ke dalam majelis. Kedua jenis produk hukum tersebut berkaitan dengan kedudukan dari MPR yang merupakan lembaga tertinggi Negara. Namun demikian setelah adanya perubahan UUD 1945 bentuk produk hukum yang dapat dikeluarkan oleh MPR adalah keputusan.

Pasal 1 aturan tambahan amandemen Undang-undang Dasar Tahun 1945 berbunyi :

Majelis Permusyawaratan Rakyat ditugasi untuk melakukan peninjauan terhadap materi dan status hukum Ketetapan Majelis Permusyawaratan Rakyat Sementara dan Ketetapan Majelis Permusyawaratan Rakyat untuk diambil putusan pada sidang Majelis Permusyawaratan Rakyat 2003.

Sebagai tindak lanjut dari adanya perubahan yang menyangkut produk hukum yang dapat dikeluarkan oleh MPR berupa keputusan, berdasarkan pada Pasal 1 aturan tambahan UUD 1945, dikeluarkanlah Ketetapan MPR No. 1 Tahun 2003 tentang Peninjauan terhadap Materi dan Status Hukum Ketetapan Majelis Permusyawaratan Rakyat Sementara dan Ketetapan Majelis Permusyawaratan Rakyat Republik Indonesia Tahun 1960 sampai dengan Tahun 2002. Sebagai penegas dari kewenangan MPR dalam mengeluarkan produk hukum berupa keputusan MPR tersebut, dikeluarkanlah Undang-undang Nomor 10 Tahun 2004 tentang Pembentukan Peraturan Perundang-undangan.

Kedudukan Ketetapan MPR dalam peraturan Perundang-undangan yang berlaku di Indonesia, sejak dikeluarkannya Ketetapan MPR No. 1 Tahun 2003 tentang peninjauan terhadap Materi dan Status Hukum Ketetapan Majelis Permusyawaratan Rakyat Sementara dan Ketetapan Majelis Permusyawaratan Rakyat Republik Indonesia Tahun 1960 sampai dengan Tahun 2002, dapat dikelompokkan menjadi beberapa bagian yaitu :

1. Ketetapan MPRS dan MPR Republik Indonesia yang dicabut dan dinyatakan tidak berlaku sebanyak 8 ketetapan.

2. Ketetapan MPRS dan MPR Republik Indonesia dinyatakan tetap berlaku dengan ketentuan masingmasing sebanyak 3 ketetapan.

3. Ketetapan MPRS dan MPR Republik Indonesia tetap berlaku sampai dengan terbentuknya pemerintahan hasil pemilihan umum tahun 2004 sebanyak 8 ketetapan.

4. Ketetapan MPRS dan MPR Republik Indonesia tetap berlaku sampai dengan terbentuknya undang-undang sebanyak 11 Ketetapan. 
5. Ketetapan MPRS dan MPR Republik Indonesia dinyatakan masih tetap berlaku sampai dengan ditetapkannya peraturan tata tertib yang baru oleh MPR Republik Indonesia hasil pemilihan umum tahun 2004 sebanyak 5 ketetapan.

6. Ketetapan MPRS dan MPR Republik Indonesia merupakan ketetapan MPRS dan MPR Republik Indonesia yang tidak perlu dilakukan tindakan hukum lebih lanjut, baik karena bersifat einmalig (final) maupun telah selesai dilaksanakan sebanyak 104 ketetapan.

Berdasarkan Ketetapan MPR No. 1 Tahun 2003 tersebut, Ketetapan MPRS dan MPR Republik Indonesia seluruhnya yang ditinjau berjumlah 139 Ketetapan. Keseluruhan ketetapan tersebut sebagaimana disebutkan di atas memiliki konsekuensi hukum tersendiri. Dalam hal ini tentu ada beberapa yang menjadi persoalan yang terkait dengan kedudukan Ketetapan MPR dalam peraturan perundang-undangan di Indonesia.

Persoalannya menyangkut Ketetapan MPRS dan MPRS yang Ketetapan MPRS dan MPR Republik Indonesia dinyatakan tetap berlaku dengan ketentuan masing-masing sebanyak 3 buah, dan Ketetapan MPRS dan MPR Republik Indonesia tetap berlaku sampai dengan terbentuknya Undang-undang sebanyak 8 buah ketetapan. Berdasarkan Pasal 2 Ketetapan MPR No. 1 Tahun 2003 tentang Peninjauan Terhadap Materi dan Status Hukum Ketetapan Majelis Permusyawaratan Rakyat Sementara dan Ketetapan Majelis Permusawaratan Rakyat Republik Indonesia Tahun 1960 sampai dengan Tahun 2002, menyebutkan bahwa Ketetapan MPRS dan MPR
Republik Indonesia sebagaimana di maksud di bawah ini dinyatakan tetap berlaku dengan ketentuan masing-masing sebagai berikut:

1. Ketetapan Majelis Permusyawaratan Rakyat Sementara Republik Indonesia Nomor XXV/MPRS1966 tentang Pembubaran Partai Komunis Indonesia, Pernyataan sebagai organisasi terlarang diseluruh wilayah Negara Republik Indonesia bagi partai komunis Indonesia dan larangan. Setiap kegiatan untuk menyebarkan atau mengembangkan faham atau ajaran Komunis/Marxisme Leninisme dinyatakan tetap berlaku dengan ketentuan seluruh ketentuan dalam Ketetapan Majelis Permusyawaratan Rakyat Sementara Republik Indonesia Nomor XXV/MPRS/1966 ini ke depan diberlakukan dengan berkeadilan dan menghormati hukum, prinsip demokrasi dan hak asasi manusia.

2. Ketetapan Majelis Permusyawaratan Rakyat Republik Indonesia Nomor XVI/MPR/1998 tentang politik ekonomi dalam rangka demokrasi ekonomi, dinyatakan tetap berlaku dengan ketentuan Pemerintah berkewajiban mendorong keberpihakan politik ekonomi yang lebih memberikan kesempatan dukungan dan pengembangan ekonomi, usaha kecil menegah dan koperasi sebagai pilar ekonomi dalam membangkitkan terlaksananya pembangunan nasional dalam rangka demokrasi ekonomi sesuai hakikat pasal 33 Undangundang Dasar Negara Republik Indonesia tahun 1945;

3. Ketetapan Majelis Permusyawaratan Rakyat Republik Indonesia Nomor V/MPR/1999 tentang penentuan pendapat di Timor-Timor tetap berlaku sampai dengan terlaksananya ketentuan dalam 
pasal 5 dan pasal 6 Ketetapan Majelis Permusyawaratan Rakyat Republik Indonesia Nomor V/MPR/1999.

Berkaitan dengan ketentuan

Pasal 2 dari Ketetapan MPR tersebut diatas apabila dikaji lebih jauh ketetapan MPR tersebut diatas kemungkinan besar terjadinya kelanggengan pemberlakuan. Ketetapan Majelis Permusyawaratan Rakyat Sementara Republik Indonesia Nomor XXV/MPRS1966 tentang Pembubaran Partai Komunis Indonesia, Pernyataan sebagai organisasi terlarang diseluruh wilayah Negara Republik Indonesia bagi partai komunis Indonesia dan larangan setiap kegiatan untuk menyebarkan atau mengembangkan faham atau ajaran Komunis/Marxisme Leninisme dinyatakan tetap berlaku dengan ketentuan seluruh ketentuan dalam Ketetapan Majelis Permusyawaratan Rakyat Sementara Republik Indonesia Nomor XXV/MPRS/1966 ini ke depan diberlakukan dengan berkeadilan dan menghormati hukum, prinsip demokrasi dan hak asasi manusia.

Langgengnya pemberlakuan terhadap ketetapan tersebut di atas lebih mendasarkan pada kesejarahan yang terjadi di masa sebelumnya di Indonesia yang sangat melarang dan menganggap partai komunis dengan segala embel-embelnya bertentangan dengan prinsip-prinsip hidup di Indonesia yang berdasarkan pada Pancasila. Meskipun demikian bukan berarti pada masa mendatang tidak terjadi perubahan dalam kehidupan kenegaraan yang ada di Indonesia. Kemungkinan-kemungkinan perubahan dari penempatan materi ketetapan MPR tersebut di atas sangat berpotensi untuk dirubah apabila political will yang dilakukan oleh lembaga yang berwenang untuk merubah wadah dari materi ketetapan MPR tersebut ke dalam peraturan
Undang-undang. Perubahan ini memang tidak begitu terlampau sulit untuk diwujudkan karena sangat terbuka untuk dilaksanakan. Pewadahan subtansi tentang larangan partai komunis dan sejenisnya serta hal-hal yang terkait dengannya dalam ketetapan MPR tersebut lebih didasarkan pada asas manfaat dari ketetapan tersebut yang masih dianggap tetap berguna dan bermanfaat.

Berdasarkan Pasal 4 Ketetapan ketetapan MPR No. 1 Tahun 2003 tentang Peninjauan Terhadap Materi dan Status Hukum Ketetapan Majelis Permusyawaratan Rakyat Sementara dan Ketetapan Majelis Permusyawaratan Rakyat Republik Indonesia Tahun 1960 sampai dengan Tahun 2002, menyebutkan bahwa Ketetapan Majelis Permusyawaratan Rakyat Sementara dan Ketetapan Majelis Permusyawaratan Rakyat Republik Indonesia sebagaimana dimaksud di bawah ini tetap berlaku sampai dengan terbentuknya Undang-undang, yaitu :

1. Ketetapan Majelis Permusyawaratan Rakyat Sementara Republik Indonesia Nomor XXIX/MPRS/1966 tentang pengangkatan pahlawan Ampera tetap berlaku dengan menghargai pahlawan Ampera yang telah ditetapkan dan sampai terbentuknya undangundang tentang pemberian gelar, tanda jasa, lain-lain tanda kehormatan.

2. Ketetapan Majelis Permusyawaratan Rakyat Republik Indonesia Nomor XI/MPR/1999 tentang Penyelenggaraan Negara yang Bersih dan Bebas Korupsi Kolusi, dan Nepotisme sampai terlaksananya seluruh ketentuan dalam ketetapan tersebut.

3. Ketetapan Majelis Permusyawaratan Rakyat 
Republik Indonesia Nomor XV/MPR/1998 tentang

Penyelenggaran Otonomi

Daerah. Pengaturan Pembagian dan Pemanfaatan Sumber Daya Nasional yang Berkeadilan serta Perimbangan Keuangan Pusat dan Daerah dalam Kerangka Negara Kesatuan Republik Indonesia sampai dengan terbentuknya undang-undang tentang pemerintahan daerah sebagaimana diamanatkan oleh pasal 18, 18A dan 18B Undangundang Dasar Negara Republik Indonesia tahun 1945.

4. Ketetapan Majelis Permusyawaratan Rakyat Republik Indonesia Nomor III/MPR/2000 tentang Sumber hukum dan tata urutan peraturan perundang-undangan.

5. Ketetapan Majelis Permusyawaratan Rakyat Republik Indonesia Nomor V/MPR/2000 tentang Pemantapan Persatuan dan Kesatuan Nasional.

6. Ketetapan Majelis Permusyawaratan Rakyat Republik Indonesia Nomor VI/MPR/2000 tentang Pemisahan Tentara Nasional Indonesia dan Kepolisian Negara Republik Indonesia sampai terbentuknya Undangundang yang terkait.

7. Ketetapan Majelis Permusyawaratan Rakyat Republik Indonesia Nomor VII/MPR/2000 tentang Peran Tentara Nasional Indonesia dan peran Kepolisian Negara Republik Indonesia sampai terbentuknya undang-undang yang terkait dengan penyempurnaan Pasal 5 ayat (4) dan Pasal 10 ayat (2) dari ketetapan tersebut yang disesuaikan dengan UndangUndang Dasar Negara Republik Indonesia tahun 1945.

8. Ketetapan

Permusyawaratan

Majelis Republik Indonesia Nomor
VI/MPR/2001 tentang etika kehidupan berbangsa.

9. Ketetapan Majelis

Permusyawaratan Rakyat

Republik Indonesia Nomor VI/MPR/2001 tentang visi Indonesia masa depan.

10. Ketetapan Majelis

Permusyawaratan Rakyat

Republik Indonesia Nomor

VII/MPR/2001 tentang

rekomendasi arah kebijakan pemberantasn pencegahan

korupsi kolusi dan nepotisme sampai terlaksananya seluruh ketentuan dalam ketetapan tersebut.

11. Ketetapan Majelis

Permusyawaratan Rakyat

Republik Indonesia Nomor IX/MPR/2001 tentang

Pembaruan agraria dan pengelolaan sumber daya alam sampai terlaksananya seluruh ketentuan dalam ketetapan tersebut.

Beberapa ketetapan yang tersebut di atas dalam pasal 4 ini telah berubah menjadi Undang-undang dan sebagian lainnya lagi belum ada yang berubah menjadi Undang-undang. Beberapa di antara ketetapan tersebut yang telah berubah menjadi Undang-undang adalah sebagai berikut :

1. Ketetapan Majelis Permusyawaratan Rakyat Republik Indonesia Nomor XI/MPR/1999 tentang Penyelenggaraan Negara yang bersih dan bebas korupsi kolusi, dan nepotisme sampai terlaksananya seluruh ketentuan dalam ketetapan tersebut yang telah dirubah menjadi Undang-undang Nomor 28 tahun 2000 tentang Penyelenggaraan Negara yang Bersih dan Bebas Korupsi Kolusi, dan Nepotisme

2. Ketetapan Majelis Permusyawaratan Rakyat Republik Indonesia Nomor XV/MPR/1998 tentang penyelenggaran otonomi daerah, pengaturan pembagian dan pemanfaatan sumber daya nasional yang berkeadilan serta perimbangan 